\title{
INTRODUCTION \\ Cross-Cultural Articulations of War Magic and Warrior Religion
}

D. S. Farrer

\begin{abstract}
Previous anthropology emphasized symbolic incantations at the expense of the embodied practice of magic. Foregrounding embodiment and performance in war magic and warrior religion collapses the mind-body dualism of magic versus rationality, instead highlighting social action, innovation, and the revitalization of tradition, as tempered historically by colonial and post-colonial trajectories in societies undergoing rapid social transformation. Religion and magic are re-evaluated from the perspective of the practitioner's and the victim's embodiment in their experiential life-worlds via articles discussing Chinese exorcists, Javanese spirit siblings, Sumatran black magic, Tamil Tiger suicide bombers, Chamorro spiritual re-enchantment, tantric Buddhist war magic, and Yanomami dark shamans. Central themes include violence and healing, accomplished through ritual and performance, to unleash and/or control the power of gods, demons, ghosts and the dead.
\end{abstract}

Keywords: embodiment, magic, performance, shamanism, sorcery, violence, warfare, witchcraft

In the post-9/11 era, the relationship of religion and magic to violence and warfare demands urgent investigation. Prior to the leveling of the World Trade Center orchestrated by the al-Qaeda suicide attacks, the sociology of religion had virtually ignored Islam. Questions of violence and religion were drawn behind the veil of supposed 'ethnocentrism'. To discuss Islam in the frame of warrior religion became politically incorrect, thereby ignoring a key insight of the great sociologist Max Weber and closing down an original avenue of inquiry. Questions of violence, war magic, and religion cannot be relegated solely to Islam, however, as a rich literature is emerging that examines even supposedly pacifist religions such as Buddhism in the context of religious violence. 
This special issue resituates the cross-cultural problematic of war magic and warrior religion firmly at the epistemological core of anthropological discourse (Evans-Pritchard [1937] 1977; Kapferer 2003). The late Neil L. Whitehead's ground-breaking volumes Dark Shamans (2002) and (with Robin Wright) In Darkness and Secrecy (2004) provide one side of the coin. While the terms 'war magic' and 'dark shamanism' appear almost interchangeable, war magic may be pitted against assault sorcery in a socially sanctioned response to attacks. Jokić (this issue) shows how the war magician and the dark shaman may be one and the same person: "[T]he same practitioner who can cure and protect his or her kin with the help of assistant spirits can also use those spirits for the purpose of inflicting harm and death to others." For Whitehead, 'semiotics' consists of "the formal properties of signs, symbols, and rituals" to which he contrasts 'poetics' or "how those signs are used performatively through time” (Whitehead 2002: 2). Accepting Whitehead's attention to historical detail as a means to enhance ethnographic accounts, his focus via poetics is expanded here in favor of regarding war magic through three primary frames: cognitive, informed by myths, signs, symbols, perceptions, and beliefs; performative (liminal ritual being apposite for the release of mystical forces); and embodiment- "an existential condition in which the body is the subjective source or intersubjective ground of experience" (Csordas 1999: 143), one that is relevant to identity and cultural performance (Farrer 2009: 39; Farrer and Whalen-Bridge 2011a: 1) as well as 'sensuous scholarship' (Stoller 1997).

The revaluation of religion, shamanism, sorcery, and magic presented in these pages refers to actual experiences of colonial violence, alongside fears of violence, and the resulting misfortunes, sickness, and death. The articles travel through Singapore, Java, Sumatra, Sri Lanka, India, Guam, and Venezuela. War magic and warrior religion are considered as symbolic and embodied practices concerned with innovation and the revitalization of tradition, tempered historically by colonial and post-colonial trajectories in societies undergoing rapid social transformation. Each essay investigates indigenous philosophies among expert practitioners. The scope of this special issue incorporates Chinese exorcists (tangkis), Javanese spirit siblings, Sumatran black magic, Tamil Tiger suicide bombers, Chamorro spiritual re-enchantment, and Yanomami dark shamans. Taken together, the articles blaze a trail through the tangled literature and myriad social practices connecting numinosity to violence and spirituality to warfare, contributing to global debates concerning contemporary spiritual innovation, revival, and revitalization.

Discourses specifically concerning war magic have arisen primarily from anthropological studies of Papua New Guinea, Southeast Asia, and Polynesia (Farrer 2009; Reay 1987; Shaw 1976). Historical accounts of war magic in Southeast Asia, such as Anthony Reid's (1988) tour de force, Southeast Asia in the Age of Commerce, document the critical importance of magic in matters of warfare, politics, and legal process. There is, of course, considerable overlap in the vast literature on magic and sorcery-especially where they relate to organized violence and death-and to some degree the terms are interchangeable. 
As an analytical concept warrior religion was largely confined to sociology (Levtzion 1999; B. Turner 1998; Weber [1922] 1991). Subsequent studies of dark shamanism, shamanic warfare, and shamanic assault have emerged from South America (Whitehead 2002; Whitehead and Wright 2004). Contemporary studies in anthropology, archaeology, history, sociology, folklore, and mythology demonstrate that warrior religion and war magic are ubiquitous social phenomena that have arisen across the globe in a diverse range of cultures. Ancient Icelandic sagas testify to the violent power of the priest-chiefs whose "influence depended on such things as physical strength, personal fame, and skill at arms, just as much as on birth and inherited wealth" (V. Turner 1985: 86). Druids worshipping the Celtic war goddess Morrighan called down lightning like rain to eradicate armies with fire and, pointing one finger, hopped around the enemy camp to cast death spells (Ross 2004: 113). Legends relate how the warrior druid, also serving as poet and king, used cunning and courage to overcome mighty foes.

Whether cowardly or courageous, cunning and trickery are integral elements of war magic that operate through framing, reframing, and misframing (Goffman 1974). During World War II, while the Nazi Party sought an 'unholy alliance' (Levenda 2002) with demonic forces and embraced its 'occult roots' (Goodrick-Clarke 1992), and the Catholic Church turned a blind eye to the persecution of the Jews, the British Army experimented with the 'dirty tricks' of war magic, including illusion, misdirection, and deception (Fisher [1983] 2004). Stage magic became war magic to outwit the 'Desert Fox', Rommel, between 1941 and 1945. Jasper Maskelyne, a professional stage magician, disguised tanks as supply vehicles, used strobe lights to make the Suez Canal disappear, and tricked the Germans into bombing a false harbor for three nights by switching around the regional lights (ibid.). The dirty tricks of war magic are the basic ingredients of modern intelligence and espionage. In many cultures, however, as in antiquity, there is a fine line between the religious virtuoso, sorcerer, healer, stage magician, and trickster. Possibly the greatest magician ever to have lived, Jesus of Nazareth "cured lunatics, paralytics, lepers, the dumb, the blind, the withered, the woman with the issue of blood and those afflicted with demoniacal possession" (Butler [1948] 1993: 73) and accomplished the most difficult magical feat of all: he raised the dead, including himself.

The pejorative use of the word 'magic' and its cognates must be recognized. During the Middle Ages, the Catholic Church in Europe developed a discourse in which 'magic', 'sorcery', and 'witchcraft' became demonizing labels to justify social exclusion, persecution, torture, tribunals, and execution. Magic, so the creed went, stood in the way of the conversion of savages, heathens, and idolaters to the true path of the righteous, which was necessary to rid the world of sin and guarantee salvation in everlasting life. In their doctrines Victorian scholars-such as Sir James Frazer, Sir Edward Tylor, Auguste Comte, Herbert Spencer, and subsequently Emile Durkheim and Max Weber-echoed this 'civilizing' prejudice that magic was a lower form of rationality in the evolution of thought, which supposedly developed through magic and religion to culminate 
in the scientific worldview. The Weberian notion that the world was entering a final rational phase of disenchantment was, however, short-lived. Yet the claim that the present era is one of re-enchantment giving witness to the rise of 'occult economies', that is, the real or imagined deployment of magical means for material ends (Comaroff and Comaroff 1999), or conversely that we have entered an era of terminal decline (the Kali Yuga), begs the question. What is apparent is the ability of people everywhere to engage simultaneously with enchanted, disenchanted, and re-enchanted modes of thinking (notwithstanding cognitive dissonance), where a "discourse of decline" (Neidel, this issue) or of amplification through the onset of a burgeoning transnational "New Age culture" (Hutton 1999: 111) may suggest changes in character as some traditional functions atrophy and others develop.

Religious thought has forever thrived in the jaws of contradiction, and this is reflected in religious practice where the management of liminality pays the rent. Christianity, like the other "great world religions" institutionalizes liminality (V. Turner 1969: 107), that is, rituals of birth, marriage, and death. The modern church, reeling under countless corroborated incidents of child abuse, nevertheless provides a source of comfort to bereaved family members in the cold industry of death. In England, bombed-out churches, the ruins of victory in World War II, are poignant reminders of a time when priests faced the awkward task of rationalizing the mass slaughter of innocents in terms of God's will. Figure 1 shows the ruins of St. Leonard's Parish Church on VE Day, with church-goers holding signs reading “Thank God," "Victory," and "We've Won.”

In their social application, religion, sorcery, and magic are nebulous polyvalent concepts that overlap and interpenetrate in complex ways. Generally speaking, magic + malice $=$ sorcery $/$ witchcraft. War sorcery here refers to the organization of ritual practices to harness magical, spiritual, and social-psychological forces that result in an opponent's misfortune, disease, destruction, or death. War magic is an umbrella term that includes war sorcery but also encompasses the various measures used to counter malign sorcerous forces, such as invulnerability magic, and the use of special formulas and amulets designed or utilized for spiritual protection. Warrior religion denotes the social organization of the means of destruction where religion provides a dividing line between 'us and them'. Given the so-called war on terror and the widespread confusion and hostility surrounding the key ideological differential of the modern world orderthat being the divide between those with and those without religious 'faith'-a new understanding of religion, secularism, and organized violence is vital.

Warfare refers to "a planned and organised armed dispute between political units” (Keith Otterbein, cited in T. Otto 2006: 23; see also Haas 1990). Warfare comprises the whole spectrum of organized violence within and outside of states, including violent encounters between individuals and small groups of people and (depending on the numbers, organization, and resources) violent antagonisms between different sets of people within communities, genocide, full-scale war between nation-states, and world war. Warfare affects every aspect of the wider society and creates high levels of personal anxiety. Long after the bloodletting desists, the reverberations of political violence 


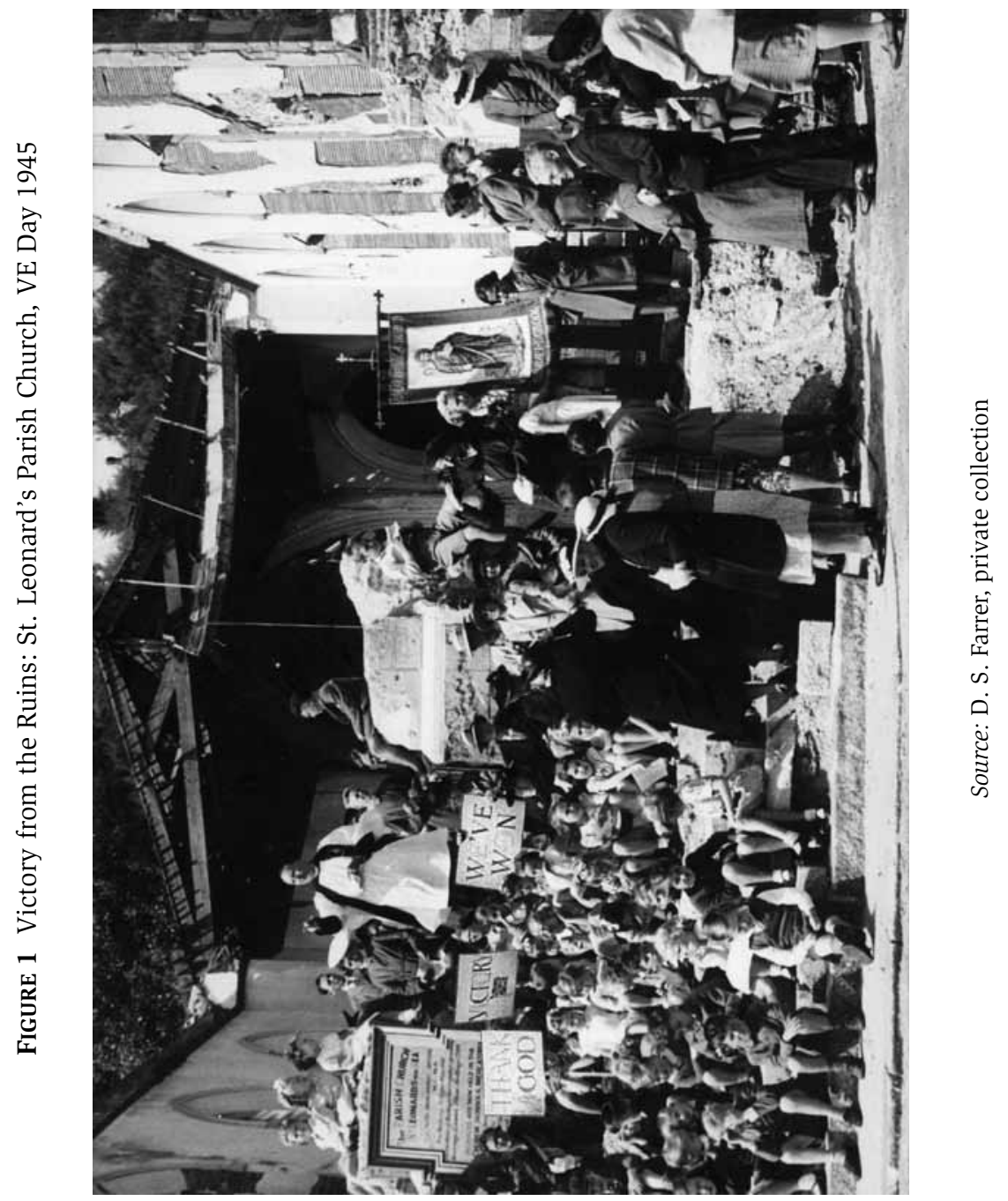


are embedded in social organization, health care, education, family narrative, and life history. The large-scale militarization and mobilization of whole populations during wartime is facilitated by a dramatic increase in the rate of workforce exploitation. Military attitudes, discipline, and factory organization spread throughout the social structures of the twentieth century. The non-military workplace was bureaucratized while the family bore the brunt of wartime shock, trauma, stress, and upheaval, repercussions of which were passed down through mental illness across the generations.

Warfare became 'total' by the end of World War I (Virilio 2004: 204), involving trench, naval, and aerial fighting between nation-states that culminated in clear victory or defeat, reparation, rebuilding, and national restructuring. The explosions, however, of the Twin Towers in New York City by the unconventional means of hijacked commercial aircraft leveled more than prime real estate and thousands of human lives. As counter "information bombs" (ibid.), the 9/11 explosions disrupted almost a century of understandings of war that had evolved following World War I. It was acknowledged that the leadership and organizational configuration of Islamic religious groups was different from their bureaucratic Western counterparts and could better be described as 'galactic' (Tambiah 1976), like stars clustered in galaxies, or, more cynically, as 'Medussan', where to chop off one snake head only results in another hundred sprouting forth to replace it. The destruction of 9/11 provoked, or justified, the United States and the United Kingdom to undertake a 'war of manoeuvre' (Gramsci 1971) in Afghanistan and Iraq. Because so-called Islamic terrorists exist beyond nation-states and territories as demarcated by the Western powers, the Bush administration, in the 2001 Patriot Act, immediately redefined 'terrorism' from a criminal activity to an act of war, thus redefining war itself.

Therefore, despite all the ink spilt on religion, magic, and warfare over the past century, we find ourselves at an academic ground zero, if not exactly illa terra virgo nondum pluviis irrigata (lit., 'virgin earth not yet watered by the rains'). Christianity is represented as some kind of 'social preservative' to 'save' culture, tradition, and the 'American way of life'. Religion, then, provides a better justification to wage war than 'weapons of mass destruction' that have gone missing or the need for oil to navigate overpowered SUVs through endless, snarled corridors of traffic. World War II is not yet over for the United States, the world's self-appointed police officer and superpower defender of 'liberty, freedom, and democracy'. The result is a society in a perpetual state of military mobilization. Trotsky's cry of permanent revolution was trumped by one of permanent war.

\section{Navigating Webs of Definition}

What, then, is the substance of religions worth their weight in blood, oil, and gold? The thorny problem of adequately defining or 'setting bounds' to magic and religion has bedeviled anthropology and leaves us with the problem of 
navigating labyrinthine webs of definition. After decades of research, Brian Morris (2006: 1) suggests a "working definition" of religion as "essentially a social phenomenon,” as opposed to Geertz's 'symbolic system', Tambiah's 'awareness of the transcendent', or Rudolf Otto's 'feeling of the numinous'. Melford Spiro (1987: 197) defines religion as "an institution consisting of culturally patterned interaction with culturally postulated superhuman beings.” Among other factors, 'superhuman' could be read as 'supernatural', 'occult', or 'numinous.' Morris (2006: 2-13) immediately doffs his cap to the main theoretical contenders, including intellectualist, emotionalist, cognitive, structuralist, phenomenological, and sociological approaches, to emphasize the continued importance of anthropology in bridging humanist and naturalist accounts. Implicitly following Weber, the institutional aspect of religion is an important definitional tool, vis-à-vis rituals, ethics, doctrines, scriptures, beliefs, congregation and church (or their equivalents), hierarchy, and emotional ethos. All of these terms, however, are problematic, and each draws us further into a seemingly endless web of definition where the centrally bound definitional point remains elusive.

\section{The Resurgence of Warrior Religion}

Religious agency exerts a powerful influence upon social behavior. Following Nietzsche (2000), Max Weber developed a sophisticated perspective that maintained the agency of religion as a counterpoint to theories that relegate religion to the status of epiphenomenon, illusion, or opiate. Weber's ([1905] 2002) insights concerning religious agency led him to theorize how sets of calculative Protestant attitudes had the unintended consequence of spawning modern 'rational' capitalist development in the West. While recognizing the rationality of Islam, and noting the great historic trading routes from the Middle East, Weber (1978: 265, 444, 474-475, 623-627) regarded Islam primarily as a 'warrior religion'. In this view, Islam prepares its followers psychologically for battle by reconciling the believers to death and the afterlife. More importantly, in Weber's opinion, the organization of Islamic ritual and worship tightly knit the community (ummah) and prepare the believers to obey orders given by the leader of the prayer. For Weber, standard organizational definitions regard religion as a group activity in which divine or supernatural entities are entreated or supplicated for the greater good, that is, for the benefit of an ethical project or community. By comparison, magic is considered a way to power employed by self-serving individuals, and sorcery is seen as magic proceeding via demonic intervention.

Weber's views concerning Islam as a warrior religion came under fire from Bryan Turner (1998) in Weber and Islam. For Turner, the Orientalism and Eurocentrism of the colonial era infected Weber's 'ideal type' of Islam. In a more subtle approach, both for and against Weber, who clearly endorses the views of the fourteenth-century sociologist Ibn Khaldun, Nehemia Levtzion (1999: 160) suggests that as long as the role of jurists, clerics, and Sufis is recognized 
in the expansion of Islam, the idea of Islam as a warrior religion may be appropriate under particular historical or social conditions and at particular phase of Islam's development, notably the early period of Islamic expansion during which nomadic tribes supported the charismatic leadership of the Prophet Muhammad. While warrior religion is well-illustrated in Islam, it operates under many guises in most societies at different points in time (see, e.g., Elliott 1998; Farrer 2011; Shahar 2008). ${ }^{1}$ During my fieldwork in Malaysia, a Muslim martial artist complained to me after prayers in the Zawiyah that clerics are "religious nerds" who do nothing but loaf about the mosque all day (Farrer 2009: 164). To follow the oral tradition (haddith) of the Prophet properly, he said, Muslims should practice archery, horseback riding, and wrestling. Nowadays, of course, this haddith extends to firearms, automobiles, and mixed martial arts. Combined with a conviction that there is nothing to fear in this world, not even death, such attitudes sustain tenacious warriors. Although de Grave and Neidel (this issue) point out that the influence of so-called modernist Islam encourages Indonesians to abandon their magical beliefs and practices, the danger of a decline in war magic is a pendulum swing in the direction of warrior religion.

\section{Beyond Primitive Religion}

Contemporary scholars who have relinquished the study of 'primitive religion' as an interesting, if misguided, enterprise are no closer to a final definition than their forebears (Sørensen 2007; Stein and Stein 2008). For some anthropologists, the rejection of a grand theory, fanned by the pre-fin-de-siècle postmodern turn, rendered any universal definition of magic or religion impossible. Klass and Weisgrau (1999), for example, claimed that studies in primitive religion were abandoned once it was realized that labeling the other as 'savage', 'barbarian', or 'primitive' is basically a subjective exercise, leading to the conclusion that questions of religion should be left for the individual to decide. Anthropologists could then approach depth psychology for insights concerning ritual and religious symbolism, set in terms of the individual's quest toward personal transformation (Morris 1987: 163-181; V. Turner 1961, 1967, 1975). Citing Rudolf Otto, Carl Jung (1969: 7) borrowed the notion of the numinosum to define religion as an experience of something beyond, as a "dynamic agency or effect not caused by an arbitrary act of will ... that seizes control of the human subject," who is always cast as victim rather than creator. This notion places the 'mystical experience' of the invaded victim at the core of religious sensibility. It is an experience that may be subsequently manipulated by charisma, magic, and ritual. The emphasis on mystical experience, however, neglects those for whom religion is merely a set of mundane rituals, or those for whom religion is a loosely accepted set of practices that are enacted at moments of crisis or celebration and are otherwise left hung out to dry.

Dramatic shifts in the understanding of violence and warfare correspond with wider shifts in the meaning of culture and religion. Drawing inspiration 
from Weber, Evans-Pritchard, Kapferer, and Whitehead, this special issue seeks to address war magic and warrior religion through the grounded particularities of their embodied ritual practice and performance. Provided that the researcher is willing and able to suspend or bracket (epoché) her cultural conceptual divisions, issues of magic and religion may emerge as specific social phenomena, leaving universal definitions for sociological exercise-at which Weber's ([1922] 1991) The Sociology of Religion remains unsurpassed. Nevertheless, whereas dark shamanism is a strategy to inflict harm, war magic operates to cure ills. As Chan (this issue) points out, the ancient Chinese ideograph 嫛 ( $y i$, physician) is comprised of an arrow in a quiver at the top left, a hand drawing a bowstring at the top right, and two dancing wu 巫 female shamans or sorcerers below. Akin to the pharmakon (remedy/poison), therefore, the central themes of war magic include violence and healing, brought about through ritual and performance, with the goal of unleashing or controlling the power of gods, ghosts, demons, and the dead (Farrer 2008; Kapferer 2004; Taussig 1987).

War magic refers to an attribute, power, or practice, whereas war magician is a (possibly hereditary) social status-that is, it is institutional (and thereby religious). Terms used to address the war magician include 'war sorcerer', 'witch', 'warrior shaman', 'war wizard', 'warrior druid', 'warrior priest', and, perhaps less commonly, 'guru', 'shaman', Shaiva, and Sufi (Mauss [1902] 2001; Winstedt [1925] 1993). While these terms reflect religious or political sensitivities, depending on circumstance, culture, and situation, they also indicate problems with the commonly employed analytical boundaries drawn between magic, sorcery, shamanism, and religion. In anthropology texts, magic is typically defined as the ability to influence others or events through supernatural intervention or agency. ${ }^{2}$ Magic is regarded as an individual enterprise that serves particular ends rather than benefiting the community at large, in contrast to religion, which serves ethical ends directed toward the wider community or society. Sorcery and witchcraft are often defined in much the same way as magic, with interstitial boundaries left arbitrary or unclear, although there is some predilection to relegate sorcery and witchcraft to malevolent, murderous, or harmful magic. Sometimes the sorcery-witchcraft distinction reflects historical European differences drawn between sorcery and witchcraft, with sorcery being looked on as a primitive and possibly rather innocuous type of magic that later evolved into maleficent witchcraft, typified in times of medieval Christianity by accusations of keeping familiars, summoning demons, and worshipping Satan (Russell and Alexander [1980] 2007).

Shamanism is deemed the earliest known form of religion, with practitioners entering into trances or altered states of consciousness in order to commune with spirits and supplicate them for the ethical community ends of healing the sick or staving off misfortune (Eliade 1972; Lewis [1971] 2003). Sorcery, in contrast, may be defined antithetically to shamanism as a ritual practice to summon or compel-not supplicate-ancestral, demonic, or nature spirits into this realm to carry out the individual and possibly unethical bidding of the sorcerer, diviner, or necromancer. This definition is, of course, almost interchangeable with the definition of witchcraft given above. 
Anthropological accounts have tended to neglect war magic and warrior religion despite the fact that the discipline emerged during the most violent century of recorded human history. Similarly, apart from a few exceptions, contemporary sociological theory has dismissed the notion of Islam as a warrior religion, viewing it as merely a reflection of Weber's Orientalism fueled by Western fears of 'conversion by the sword'. In social and cultural anthropology, war magic and warrior religion make only the occasional ethnographic guest appearance, usually being relegated to parentheses, a footnote, or an aside. War magic and warrior religion have predominantly been framed in the margins of studies that focus on artwork, area studies, cults, curiosities, curatives, dance, ghosts, hunting, jewelry, legal culture, the occult, performance, poisons, power objects, possession, religion, ritual, scarification, secret societies, sorcery, the supernatural, tattoos, trance, weapons, witchcraft, and violence. In contrast, this special issue resituates the cross-cultural problematic of war magic and warrior religion in its rightful place at the epistemological core of anthropological discourse.

\section{The Eclipse of War Magic}

The eclipse of war magic in anthropology dates back to the time of Bronislaw Malinowski, whose lack of attention to this topic is curious. It seems that he examined in great depth almost every conceivable type of magic except war magic, which was relegated to tantalizing asides on uncut groves or boma (Malinowski [1935] 1965: 87). The film Bronislaw Malinowski: Off the Veranda (Singer 1985) points out that, during his Trobriand fieldwork, Malinowski lived right next door to the magician for his own protection. Another ethnographic film, Trobriand Cricket (Leach 1976), provides an intriguing glimpse of Trobriand war magic and, in the process, advances an implicit critique of Malinowski. Here war magic is shown transposed onto cricket, a game introduced by missionaries to inculcate discipline and rule-governed competitive behavior as an alternative to internecine village revenge attacks. In the Trobriand adaptation of cricket, the wicket posts had to be situated closer together than in the Western game and the pitch made considerably longer due to the Trobrianders' accuracy in throwing the ball-an ability honed by hurling spears. The resounding chant "PK," intended to make the catcher's hands stick like glue, sounds amusing amid the dance antics of tribesmen marching like soldiers or stretching out their arms to imitate airplanes landing. However, sticking, catching, holding, and seizing are key aspects in combat, sorcery, and witchcraft alike. For Malinowski (1948: 14), the function of religion is to help the community tackle the universal and inescapable social fact of death, whereas magic functions as insurance against uncertainty. As far as 'uncertain situations' go, few can be more precarious than modern violence and warfare, with their threat of impending sudden death. Despite his copious field notes on the subject, Malinowski's neglect of war magic is unsettling and poses an enigma for further research. 
Data provided by the Trobriand war magician Kanukubusi led Malinowski ([1922] 2013: 409) to the important discovery that "magic rests in the belly." Although Malinowski made a great advance in considering magic from the unified perspective of the spell, the ritual performer, and the performance, he overemphasized the spell at the expense of the embodied practice of magic. Colonial ethnography experienced difficulties in conceiving of embodied magic. Instead, it emphasized the importance of spells, the holy word, or incantations over the embodied ritual practice or performance of magic and religion (Farrer 2009). In Southeast Asia, however, Islamic utterances or prayers introduce, close, or may utterly displace so-called animist spells in ritual performances of supernatural phenomena. Here, contra-Malinowski, the importance of the spell is secondary to magical performance (see also Tambiah 1968, 1985, 1990). Such performances include walking on fire, eating broken glass, climbing barefoot up a ladder of knives, and dipping one's hands into cauldrons of scalding water, boiling oil, or molten tin (Farrer 2009: 232-243; Waterson 1995: 94). In Asia, sorcery, mysticism, shamanism, and magic all blur into religion. Consequently, a focus on war magic and warrior religion problematizes and destabilizes taken-for-granted Western conceptual boundaries between magic and religion, body and soul, real and unreal, now and the hereafter.

\section{The Mastery of Souls}

Returning to the web of definitions for sorcery, magic, and witchcraft, the most well-known ethnographic definitions derive from the Africanist model espoused by Evans-Pritchard ([1937] 1977). Evans-Pritchard configured the witch as the unsuspecting individual holder of a witchcraft substance contained within the belly, in contrast to the sorcerer who is the knowing member of a secret society. The description of the viscous witchcraft substance in the belly of the Zande witch is strongly reminiscent of that alluded to by Malinowski years earlier. ${ }^{3}$ Localized ethnographic definitions and distinctions, however, floundered once they were applied to other ethnographic regions, where foreign regional divisions between sorcery, witchcraft, shamanism, and magic proved inadequate. In this connection, contributions to Michele Stephen's (1987b) edited volume Sorcerer and Witch in Melanesia reveal that Evans-Pritchard's model fails to apply in New Guinea and more widely across Southeast Asia, where specialists in ritual, religion, and magic are better characterized by their 'mastery of souls' (see Stephen 1987a). The capability to affect the destiny of souls, or in Sufi terms 'to knock someone's leaf from the tree of life' in order to cause misfortune, suffering, and death, betrays an ability harbored in war magic. According to Reay (1987: 89-91), however, war sorcery involves manipulating objects belonging to the victim, as opposed to war magic proper, which proceeds through ritual and incantation-a somewhat arbitrary distinction between magic and sorcery that need not detain us here. A more useful concept is that of war magic employed as a form of 'defensive magic' (often emphasizing protection, invulnerability, or invincibility) against 
'offensive magic' (consisting of hostile supernatural acts of witchcraft or sorcery), whether or not the latter may be considered subjective or objective, passive or aggressive, intentional or denuded of agency.

A paternalistic mission of representation in advocate anthropology previously meant that the 'dark' or evil side of informants and their social doings was glossed over or ignored by anthropologists seeking to promote their informants' culture in a positive way, especially against racist colonial and imperialist powers. Moving toward a post-colonial era in which the actions of political elites are increasingly distanced from their historical antecedents means that a space has opened for ethnography to recognize that 'they lie, we lie' (Metcalf 2002) and that anthropology has gained ground to become grittier and more subtle, relevant, and realistic. It is not surprising that the notion of dark shamanism emerged from Amazonia, where the liberal trope of the heroic anthropologist-supposedly representing impoverished downtrodden people who were otherwise left without a voice-was rendered irrelevant by the poisoning of Neil Whitehead, making him a victim of shamanic assault (Whitehead and Wright 2004).

While religion purports to be engaged in the ethical project of becominghuman, to make people live decent and civilized lives, for Deleuze and Guattari ([1987] 2004) the warrior tends toward 'becoming-intense', 'becoming-animal'. Following Dumézil (1970), Deleuze and Guattari ([1987] 2004: 232-309) note that the war machine entails all kinds of 'becomings-animal', insofar as the warrior remains a liminal and transgressive figure, exterior to the state even if subordinated to it. Becoming-animal involves the fighters of the war machine undergoing intense ritual ordeals, possibly enduring bodily alteration through tattooing or scarification as well as psychological trials of privation, torment, and intimidation. Outside of the conditions of war, hunting, shamanic trance, drumming, dance, yoga, and martial arts provide opportunities for becomingintense, becoming-animal (Farrer 2013). Intense animal becomings, for example, are suggested in the practice of hatha yoga (Farrer 2009: 124-127), with adepts adopting animal postures such as 'the crow' and 'the cobra' and other stances known as 'warrior poses'. Or consider another example from martial arts. In the Javanese martial art of the 'evil tiger' (silat siluman harimau) (Farrer 2006: 41; 2009: 268-269), becoming-animal to summon an ancestral spirit of a tiger or crocodile, as a spirit-helper, is the culmination of a ritual practice where the martial artist lies in an open grave for eight consecutive nights (Farrer 2009: 255-256, 269).

Becoming-animal may also illustrate more sinister practices. In Guyana, kanaimà shamans, for example, operate in small packs to assault victims (often vulnerable women or children), whom they seize from behind in order to dislocate the victims' shoulder or fingers. This is followed by a subsequent attack, taking place up to a year or two later, in which the victims are forced to their knees so that a poisonous snake can bite their tongues, and they are then made to lie face down. The victim's anus is penetrated with the rough tail of an iguana or armadillo that is vibrated to destroy the anal wall. The anal sphincter is then slit and the enlarged wound prized open with a flexed twig 
so that the target's rectum can be stuffed deeply with bags of astringent herbs. After the victim's agonizing death (usually by dehydration), the kanaimà practitioners attend the victim's grave and slide a stick into the corpse so that they can taste the maba (honey-like) "juices of putrefaction" (Whitehead 2002: 14-15). A climate of fear, terror, and revenge is perpetuated by such revolting and offensive practices.

From another angle, Kapferer (1991, 1997, 2003) points out that sorcery exists to attain power. Ideology, politics, and warfare-and religion, sorcery, and magic-are familiar bedfellows. Each set of ideas exists as interlinked, interwoven, multiplicitous social phenomena that can only be artificially teased apart from the others in the set for the purposes of definition and description. In The Unabridged Devil's Dictionary, Ambrose Bierce ([1881] 2000: 216) perceived sorcery as the "ancient prototype and forerunner of political influence." Bierce defines politics as a "strife of interests masquerading as a contest of principles" where public affairs are conducted "for private advantage" (ibid.: 184). To the skeptical unbeliever, political demonstrations of religiosity appear to be epiphenomenon, subsidiary posturing, hypocrisy, or ideological gloss to the war for oil and control of the planet's resources. Nevertheless, religion must be regarded as a central actor in the theater of war. Whether Islamic, Buddhist, Judaic, or Christian, revitalized religions can provide the moral switch to activate war machines and terror networks in the service of apparent global, human, and divine interests in order to secure, symbolic, cultural, social and economic capital.

\section{Introduction to the Articles}

The articles presented in this special issue discuss demon-killing exorcists in the Singapore Chinese diaspora (Margaret Chan), Javanese secret society initiations (Jean-Marc de Grave), black magic in Sumatra (J. David Neidel), Tamil Tiger ritual, war, and assassination in Sri Lanka (Michael Roberts), Chamorro re-enchantment on Guam (D. S. Farrer and James D. Sellmann), Yanomami shamans in Venezuela (Željko Jokić), and tantric Buddhist war magic in India (Iain Sinclair). The methods employed are predominantly ethnographic-Chan, de Grave, Farrer, Neidel, and Jokić are ethnographers. The essays engage with an interdisciplinary literature, including social anthropology (de Grave, Farrer, Jokić, and Neidel), theater studies (Chan), religious studies (Sinclair), and history (Sellmann and Roberts).

In "Tangki War Magic: The Virtuality of Spirit Warfare and the Actuality of Peace," Margaret Chan explores exorcist war magic in tangki Chinese spirit-medium worship. Within the communities of the Hokkien diaspora in Taiwan and Southeast Asia, tangki worship-whose origin stretches back to pre-Sinic tribal rituals performed five thousand years ago-remains active. In tangki worship, warrior gods become incarnate through medium possession in order to kill evil spirits. Tangkis are thus spirit-mediums operating as the exorcist protectors of their communities. Devotees consult tangkis to cure illness, 
change their luck, or solicit oracles. The entranced tangki cures by vanquishing disease-causing malevolent demons, brings good luck by driving away the spirits of ill fortune, and advises on metaphysical strategy through oracles.

Tangki Chinese spirit-medium worship has no liturgical canon but instead emphasizes the performance of war magic ritual. It is a ritual theater of spirit-possessed mediums believed to be warrior gods incarnate: beyond representation, tangkis provide a virtual "interactive magic." Bloody acts of self-mortification present the inherent violence of war. Self-mortification, piercing the flesh with rods, or injuring the body with swords or macelike weapons is the hallmark of tangki performances in which the tangki opposes evil demons. Tangkis pierce their bodies with swords and rods in order to take on the spirit-power imbued in these weapons. Driven into the flesh, the weapons supercharge the tangki with spirit-power. Adopting Buddhist concepts of self-mortification, contemporary acolytes pierce themselves with ceiling fans and fluorescent tube lights, and in 2007 a woman poked a modified bicycle frame through her face. Given the virtuality of tangki war magic, ritual theater is made relevant to a new generation of devotees, who are assured by spirit-warriors that their everyday life will be "an actuality of pingan (peace and safety)."

In "Javanese Kanuragan Ritual Initiation: A Means to Socialize by Acquiring Invulnerability, Authority, and Spiritual Improvement,” Jean-Marc de Grave probes kanuragan, a secretive Javanese initiation ritual linked to the cult devoted to a person's four sibling spirits. For de Grave, kanuragan develops the process involved in the mystical acquisition of authority. His article describes the process of transmission, the people involved in such practices, and the role that kanuragan plays in Javanese society for security, warfare, and healing. A fundamental use of kanuragan is to "gain strength and invulnerability," a purpose that may be served by "external entities called aji" that are transmitted by the master. Soldiers, fighters, politicians, and the police obtain mantras to render them invulnerable to blades, spears, and bullets. Other powers include invisibility (aji siluman), the destruction of evil ghosts, invulnerability to wild animals, and protection against poisonous animals. De Grave illustrates his article with ethnographic data provided by Mbah, a kanuragan master, who describes war magic being used against the Dutch forces in the anti-colonial war of 1945-1949.

The Javanese employ their sibling spirits as a self-help source for a range of issues related to health and welfare. De Grave shows that kanuragan is regularly used in Java for warlike and health purposes and ties this to Javanese mythology, cosmology, and Sufism. From the traditional Javanese perspective, kanuragan is a valuable cultural activity; however, the Indonesian state and modernist Islamic clerics regard it as a primitive and dangerous pre-Islamic cultural trait that should be excised. From the standpoint of modernist, orthodox, and radical Islam, kanuragan includes black magic, such as the declared ability of Rama Hari to transform himself into a black panther. Despite contemporary Islamic marginalization, kanuragan continues to attract adherents in secret, especially functionaries of the state. De Grave concludes that "[t]he development of radical Islam after the fall of Suharto in 1998 ... has given birth to another form of 
warrior religion." Whether this trend is more threatening toward Javanese war magic than modernist Islam or secularism remains to be seen.

In "Discourse of Decline: Local Perspectives on Magic in Highland Jambi, Indonesia,” J. David Neidel examines black magic in central Sumatra. Highland villagers are feared by many people in the neighboring lowlands due to their reputation for black magic. Drawing on two years of ethnographic research in highland Jambi, Neidel's article foregrounds emic perspectives to reveal local conceptions of supernatural powers. The ability to cause sickness or death in a distant target is the form of magic most often discussed by outsiders, but this is only one of a large repertoire of supernatural abilities recognized and/or practiced by highland peoples. These powers tend to "focus on killing or disabling an enemy or, conversely, on providing protection from attacks by humans, wild animals, or supernatural beings" and thus constitute a form of war magic. Relying on first- and third-person accounts, Neidel describes the various pathways through which supernatural abilities are acquired and the types of peopleincluding lowlanders-who seek out such powers. In doing so, his discussion draws links between the beliefs and practices surrounding sorcery, ancestral worship, spirit possession, and shamanism.

Neidel asserts that “[i]t would appear to be widely held in highland Jambi that the potency of magical powers has declined over time. Village ancestors, whose exploits are recorded in village histories and legends (tambo), are widely believed to have engaged in truly amazing feats of magical prowess, such as flying to the island of Java, raising the dead, or creating new stream channels overnight." Such deeds are now believed to be beyond the abilities of present-day practitioners. Neidel discusses various reasons for this perceived "decline in potency," attributing reasons to developments in education, better medicine and health-care facilities, improvements in transport and communications, and changes in political representation that have marginalized the necessity for supernatural intervention. He reports a colleague's view that, due to the increase in economic living standards, "people in the region have become malas membunuh orang (lazy to kill people).” Neidel concludes that because of "the influence of modernist Islam," people in highland Jambi have abandoned their magical beliefs and practices "on the grounds that magic is immoral or no longer needed, not that it is irrational or illogical." The notion that magic adapts to modernity is, of course, well-explored by many authors, following the Comaroffs (1999). Neidel's “discourse of decline" provides a new twist on the theme, whereby narratives of decline that do not attribute the decline to Western modernity offer protection against the subversive nature of modern, secular materialism. ${ }^{4}$

Michael Roberts, in "Encompassing Empowerment in Ritual, War, and Assassination: Tantric Principles in Tamil Tiger Instrumentalities," explains the defensive/violent origin of symbolic and iconic representations where "supramundane forces” act as guiding principles for social action. For Roberts, the LTTE was "one of the most innovative insurgencies in the history of insurrection" whose personnel extended and adapted the available cosmologies. To grasp the "enchanted practices" of the Tamil Tigers, Roberts works through a 
series of “interpretative leap[s]" based upon journalists' reports, personal communications, photographs, and his own travels in Sri Lanka.

Roberts spurns the demonizing language of terrorism applied to the Tamil Tigers in his discussion of the kuppi, a vial of cyanide that the Tamil Tigers bite upon to commit suicide rather than be captured. Uyirayutham, one of the fundamental principles of the LTTE, "refers to the gifting of one's life as a weapon." In this way, defensive suicidal action acts as a gift of the self. Thus, Tiger identity was one of "selfless zeal" embodied in the kuppi cyanide capsule. Roberts reveals that the kuppi and thäli are similar in appearance: "In its original form, the thāli was a turmeric-stained string ... placed around a woman's neck by her spouse at the rite finalizing their marriage," signifying a "permanent bond." Other "rites of encompassing protection" include sacred rings and chains, kolam designs drawn by women daily upon the threshold, the nūl kaddu charmed string worn around the waist of boys, rites of pradakshina (collective circumambulation of the village)-all of which bespeak "the power of encirclement."

Tantric rites and amulets thus provide examples of what Roberts refers to as "encompassment in Hindu practices," where "protection [is] sought through ... 'astrological alignment', a form of parallelism or 'analogue magic'.” Cosmic encirclement shows that the "devotee seeks to disembody him- or herself in the process of embodying the divine figure that he or she is propitiating" in an attempt to 'fuse' with the chosen deity, given that deities can alternate between benevolent protection and malevolent cruelty. According to Roberts, "[s]uch practices are facets of the generalized technology of 'beguilement', a modern form of enchantment that works within and through the psychology of instrumental rationality."

Drawing upon two years of ethnographic fieldwork in South America, Željko Jokić reflects upon Yanomami combative, predatory, assault, and defensive shamanism in "Shamanic Battleground: Magic, Sorcery, and Warrior Shamanism in Venezuela." His research challenges New Age and other one-sided misrepresentations of shamanism that deny cultural differences and consequently misplace the subject. Jokić argues that the exclusion of malign practices misrepresents other life-worlds to reproduce "colonial ways of knowing." He indicates that "[d]estructive aspects of Yanomami shamanism and sorcery still persist in a contemporary post-contact situation of culture change." Jokić discusses assault shamanism from the victim's standpoint and from the perspective of the predator shapori (shaman). Yanomami shamans and their spirit-helpers (hekura) engage in hostile acts to inflict misery and death on shamans and others from distant villages. Victims are primarily children. Hostile magical assaults are motivated by competition for power and prestige, jealousy, and vengeance.

Whereas the principal motive for magical assaults is retribution for past deaths, the shapori utilize their hekura to attack and kill their enemies and to cure their own people. Sensitive to the "moral ambiguity" of the shapori, Jokić distinguishes offensive from defensive shamanistic activities, stating: "While a shapori can save life, he can also take life. He is responsible for order but 
can also create disorder. He becomes both protector and defender of the community, shielding his people from the intrusions of the outside hekura and enemy shamans." In Jokić's view, the categories of shaman and sorcerer overlap, with the exception of ôka sorcery, "a technique of covert war magic that can sometimes trigger a real war." Õka sorcery involves poisonous powder made from the aroari plant: the sorcerer blows the powder "into the direction of a passer-by on the forest path, either from a distance or nearby through a blowpipe or from the palm of his hand." Even the shapori may not prevent the resulting agonizing death.

For Jokić, "magical practices and the accompanying social experience of violence, sickness, and death are first and foremost embodied practices." To paraphrase Jokić, the shapori employ their hekura to access human bodies during healing and killing sessions: they either occupy the victim directly or detect and extract an object of witchcraft or other invading hekura. Via the work of his hekura, the shapori discovers the "body fault" or spirit-intruder in a victim or personally intrudes into another's body. Jokić emphasizes that the shapori's malevolent activity or "supernatural warfare" must take into account non-human acts driven by the "cannibalistic nature" of the hekura spirits, demanding to be fed human flesh. Occasionally, shapori must kill in order to appease the spirits and spare the lives of their own relations. Finally, Yanomami shapori who intentionally engage in predatory acts are fully endowed with the cannibalistic characteristics of malevolent spirit-beings-chief of whom is Irariwë (Jaguar)-during ecstatic trances fueled by dance, trance, and psychotropic snuff.

In "Chants of Re-enchantment: Chamorro Spiritual Resistance to Colonial Domination,” D. S. Farrer and James D. Sellmann fuse Farrer's three-year ethnographic case study with findings from Sellmann's investigations into ancient Chamorro philosophy. The Chamorro people nowadays live predominantly on Guam, a remote island in the Pacific referred to as 'the tip of the spear' due to its occupation as a vital military base for the American global superpower. Hence, in this article war magic and warrior religion are conceptualized as "embodied cultural positions that reflect and respond to economic, military, and colonial conditions," providing a lens to study "cognitive, embodied, and practice-based forms of resistance to domination.” The article commences with an action that may be perceived as a gesture of indigenous defiance to colonial domination-or alternatively as a drug-induced momentary lapse of reasonwhen Leonard Z. Iriarte, a territorial conservation officer, shot down a B-52 bomber with an automatic rifle. This action must be understood in terms of the legacies of Spanish and American colonial occupation and the resurgence of belief in the supernatural powers of ancestral ghosts.

Farrer and Sellmann contend that the 'ancient Chamorro' cosmology and worldview are exemplified by the use of ancestral skulls in warfare, where skulls were used to line trenches in magical battle formations against the Spanish. When the skulls were trampled underfoot in 1700 after a 30-year war, " $[\mathrm{t}]$ he Chamorros did not merely surrender to the Spanish; they surrendered to their ancestors." In the process of Spanish colonial conversion, 
the Chamorro substituted the ritual use of human skulls for the worship of a crucified god, and, as a result, the Chamorro "deathscape has shifted from skulls and sharpened leg bones to a respectful fear of spirits, ghosts, and taotaomo'na [ancestral ghosts]." War magic and warrior religion are thus parallel forces in conflict. Sixteenth-century priests destroyed the power of the skulls in favor of religious conversion, procession, and confession, which were used as ideological weapons in the battle for human souls. Although the Spanish colonizers decimated the Chamorros and attempted to eradicate their culture, including dance and chant, the Chamorro language survived, providing the rudimentary elements for the revival of ritual chant (lålai). Stripping away the Spanish loan words, I' Fanlalai'an, a contemporary Chamorro chant group led by Iriarte, "re-creates ritual context using arcane but vital indigenous words." The chant is a form of Chamorro artistic expression to facilitate the respectful remembrance and invocation of the ancestors, through the chant compositions and the act of chanting itself. The taotaomo'na, feared and revered on Guam, thus provide the basis for the emergence of a new religion, Chamorro spiritualism, practiced by I' Fanlalai'an, whose self-professed mission is "to define Chamorro culture."

Iain Sinclair in "War Magic and Just War in Indian Tantric Buddhism" contemplates Buddhist war magic. Recent scholarship has lifted the doctrinal evasion of violence in Buddhism to permit subtle and realistic accounts that discuss war magic, albeit denying specifically Buddhist war or Buddhist violence. Sinclair deciphers Buddhist texts, written in the original Sanskrit in the seventh to the thirteenth centuries, to outline and discuss defensive magic, invocatory magic, yogic magic, and black magic for "paralyzing armies," read alongside the justifications for war magic developed in tantric Buddhist communities. While tantric Buddhist scripture execrated killing, people living in classical India were inevitably exposed to war. Sinclair emphasizes that " $[\mathrm{t}] \mathrm{he}$ preservation of life in war is ... regarded as paramount, even-especially-in a last-ditch battle to preserve non-violent Buddhist ideals." Defensive war magic was pacifist in nature and aimed to halt or disperse armies before they had the opportunity to engage combatants or spill blood. Yet destructive war magic also developed. Hence, although war magic was predominantly directed at avoidance to nullify a threat or to stop an advancing military force, an "immobilized army" might not just suddenly fall silent but be "frozen to death in a magically summoned blizzard."

Sinclair explains that 'invocatory' war magic was used to coax "a powerful deity to intervene on the practitioner's behalf" and was employed to "infuse the swords, maces, and soldiers' armor with the mantras." Some techniques were more fanciful, such as "the tantric master [riding] naked on an elephant to the enemy encampment, holding a skull bowl 'full of excreta, phlegm, and so on.' which he imbibes and spits in their direction." Sinclair contrasts such practices with the "war magic of the yogin," which relied upon "direct personal identification with the deity." Meditations included "Stunning All Armies" by "visualizing mountain-sized forms dropped upon the enemy's head." Other forms discussed include the "possibility of killing with a thought." As Sinclair notes, 
such "magical slaying, along with other transgressive acts enjoined in the higher tantras, can be sanctioned insofar as it is a manifestation of transcendence."

War-magic operations prescribed in liturgy and incantations give directions "to invoke the protective powers of a spirit, bodhisattva, or other such Buddhist object of worship" through the repetitive recitation of mantras at appropriate times and in appropriate places, utilizing magic circles and talismans. Sinclair notes: "Magic provided a means for Buddhists to wage war without engaging in hand-to-hand combat, which was out of the question for the monastic class and most laypeople." In conclusion, Sinclair's article shows that Indian Buddhists turned their attention to war, but they did not resort to 'holy war'. Fundamentally, for Sinclair, tantric war magic emerged as a response to the inevitability of war, eventually becoming consolidated in a system that produced "a clear definition of a just war-one that was defensive, unavoidable, dispassionate, and minimally harmful, waged against a systemically violent opponent."

Each of these articles contributes to the contemporary debate on religious revitalization and innovation. With the omission of occult ethnography in Africa, ${ }^{5}$ our coverage cannot profess to be global or comprehensive, but the articles herein do provide in-depth accounts of particular practices located in contemporary Asia, the Pacific, and South America. War magic and warrior religion suggest and invite research into the revival of indigenous spirituality that strives toward embodied empowerment, anti-colonialism, and the reenchantment of the world, often through the development of occult abilities or enhanced supernatural potency. In places where magic is shown to be in decline, this seems due to the onslaught of religious fervor. Magical, spiritual, or religious attributes fuel charismatic leadership and add legitimacy to groups and organizations struggling to revive, redefine, transform, or maintain cultures threatened by rapid social change and instability. Invulnerability, exorcism, and sacred magical cures provide comfort by reinforcing cultural continuity despite the fact that some of these ritual practices may be modern innovations rather than relics from the distant past.

Foregrounding embodiment and performance in war magic and warrior religion collapses the mind-body dualism that has resulted in an interminable inquiry into magic (whether read as 'primitive mentality' or the 'savage mind') versus rationality to highlight social action historically pursued through embodied practice and performance. This has provided a method to re-evaluate religion and magic from the perspective of the practitioner's and the victim's embodiment in their experiential life-world. War magic and warrior religion promote dance, trance, hallucinogens, the self-infliction of pain, suicide, poisoning, and murderous revenge attacks. Yet poison inevitably appears alongside remedy, where war magic operates as an antidote for assault sorcery, colonial occupation, political oppression, and threats from enemy invasion. 


\section{Acknowledgments}

This research project commenced in 2003 and follows up my doctoral research, which was subsequently published in 2009 as Shadows of the Prophet. Throughout this period, John Whalen-Bridge has been a source of encouragement and constructive criticism. Roxana Waterson and Syed Farid Alatas played important roles in the development of my thought. I am especially grateful to Ellis Finkelstein for many years of epigrammatic encouragement. Julie Farrer, my wife, gave me the freedom to pursue my occult interests. Thanks to Knut Rio, Tom Mountjoy, and Shawn Kendrick for editing the issue. The authors featured in this issue deserve my special thanks. Aside from her own article, Margaret Chan critically reviewed the introduction and my co-authored contribution. Željko Jokić provided technical support when all else failed. J. David Neidel patiently endorsed the project from the outset, James D. Sellmann joined halfway through, and Iain Sinclair swiftly entered toward the end. Michael Roberts initiated me to Social Analysis through the special issue on "Noble Death." Jean-Marc de Grave reviewed the introduction and provided insightful comments. Initially, Neil Whitehead agreed to contribute to this issue, although he subsequently withdrew. It is with regret that this issue is being published after his death.

D. S. Farrer is an Associate Professor of Anthropology and Micronesian Studies and Anthropology Program Coordinator at the University of Guam. He is the author of Shadows of the Prophet: Martial Arts and Sufi Mysticism (2009), and co-editor (with John Whalen-Bridge) of Martial Arts as Embodied Knowledge: Asian Traditions in a Transnational World (2011). His research specialties include the anthropology of performance, visual anthropology, and the anthropology of art with a regional focus toward Southeast Asia and the Pacific.

\section{Notes}

1. On this topic, see also the articles by Chan, Roberts, and Sinclair in this issue.

2. See Klass (1995) for a critique of the notion of the 'supernatural'. See also Gell (1998).

3. Compare this to the remarkable, deep-gray blob that Edith Turner et al. (1992: 14) said emerged from the back of a patient during the ilhamba, a shamanic operation, in Zambia.

4. I am indebted to the manuscript reviewer for this observation.

5. On African occults, see Kiernan (2006). 


\section{References}

Bierce, Ambrose. [1881] 2000. The Unabridged Devil's Dictionary. Ed. David E. Schultz, and S. T. Joshi. Athens: University of Georgia Press.

Butler, E. M. [1948] 1993. The Myth of the Magus. Cambridge: Cambridge University Press.

Comaroff, Jean, and John L. Comaroff. 1999. "Occult Economies and the Violence of Abstraction: Notes from the South African Postcolony." American Ethnologist 26, no. 2: 279-303.

Csordas, Thomas J. 1999. “Embodiment and Cultural Phenomenology.” Pp. 143-162 in Perspectives on Embodiment: The Intersections of Nature and Culture, ed. Gail Weiss and Honi Fern Haber. New York: Routledge.

Deleuze, Gilles, and Félix Guattari. [1987] 2004. A Thousand Plateaus: Capitalism and Schizophrenia. Trans. Brian Massumi. London: Continuum. Originally published in 1980 as Mille plateaux, vol. 2 of Capitalisme et schizophrénie.

Dumézil, Georges. 1970. The Destiny of the Warrior. Trans. Alf Hilterbeitel. Chicago: University of Chicago Press.

Eliade, Mircea. 1972. Shamanism: Archaic Techniques of Ecstasy. Trans. Willard R. Trask. Princeton, NJ: Princeton University Press.

Elliott, Paul. 1998. Warrior Cults: A History of Magical, Mystical and Murderous Organizations. London: Blandford Press.

Evans-Pritchard, E. E. [1937] 1977. Witchcraft, Oracles and Magic Among the Azande. Oxford: Clarendon Press.

Farrer, D. S. 2006. “'Deathscapes’ of the Malay Martial Artist.” Social Analysis 50, no. 1: 25-50.

Farrer, D. S. 2008. “The Healing Arts of the Malay Mystic.” Visual Anthropological Review 24, no. 1: 29-46.

Farrer, D. S. 2009. Shadows of the Prophet: Martial Arts and Sufi Mysticism. Dordrecht: Springer.

Farrer, D. S. 2011. "Coffee-Shop Gods: Chinese Martial Arts of the Singapore Diaspora.” Pp. 203-237 in Farrer and Whalen-Bridge 2011b.

Farrer, D. S. 2013. "Becoming-animal in the Chinese Martial Arts.” Pp 215-246 in Living Beings: Perspectives on Interspecies Engagements, ed. Penny Dransart. ASA Monographs No. 50. London: Bloomsbury.

Farrer, D. S., and John Whalen-Bridge. 2011a. "Introduction: Martial Arts, Transnationalism, and Embodied Knowledge.” Pp. 1-25 in Farrer and Whalen-Bridge 2011b.

Farrer, D. S., and John Whalen-Bridge, eds. 2011b. Martial Arts as Embodied Knowledge: Asian Traditions in a Transnational World. New York: SUNY.

Fisher, David. [1983] 2004. The War Magician: The Man Who Conjured Victory in the Desert. London: Weidenfeld \& Nicolson.

Gell, Alfred. 1998. Art and Agency: An Anthropological Theory. Oxford: Oxford University Press.

Goffman, Erving. 1974. Frame Analysis: An Essay on the Organization of Experience. Boston: Northeastern University Press.

Goodrick-Clarke, Nicholas. 1992. The Occult Roots of Nazism: Secret Aryan Cults and Their Influence on Nazi Ideology. New York: New York University Press.

Gramsci, Antonio. 1971. Selections from the Prison Notebooks. Ed. and trans. Quintin Hoare and Geoffrey Nowell Smith. London: Lawrence and Wishart.

Haas, Jonathan, ed. 1990. The Anthropology of War. Cambridge: Cambridge University Press. 
Hutton, Ronald. 1999. The Triumph of the Moon: A History of Modern Pagan Witchcraft. Oxford: Oxford University Press.

Jung, C. G. 1969. The Collected Works of C. G. Jung. Vol. 11: Psychology and Religion: West and East. Ed. and trans. Gerhard Adler and R. F. C. Hull. 2nd ed. Princeton, NJ: Princeton University Press.

Kapferer, Bruce. 1991. A Celebration of Demons: Exorcism and the Aesthetics of Healing in Sri Lanka. 2nd ed. Bloomington: Indiana University Press.

Kapferer, Bruce. 1997. The Feast of the Sorcerer. Chicago: University of Chicago Press.

Kapferer, Bruce, ed. 2003. Beyond Rationalism: Rethinking Magic, Witchcraft and Sorcery. New York: Berghahn Books.

Kapferer, Bruce. 2004. "Ritual Dynamics and Virtual Practice: Beyond Representation and Meaning." Social Analysis 48, no. 2: 35-54.

Kiernan, James, ed. 2006. Modernity and Belonging. Vol. 4: The Power of the Occult in Modern Africa: Continuity and Innovation in the Renewal of African Cosmologies. Berlin: LIT Verlag.

Leach, Jerry, dir. 1976. Trobriand Cricket: An Ingenious Response to Colonialism. 50 min. Documentary film. Produced by Gary Kildea and Jerry Leach.

Klass, Morton. 1995. Ordered Universes: Approaches to the Anthropology of Religion. Boulder, CO: Westview Press.

Klass, Morton, and Maxine K. Weisgrau. 1999. "Introduction." Pp. 1-6 in Across the Boundaries of Belief: Contemporary Issues in the Anthropology of Religion, ed. Morton Klass and Maxine K. Weissgrau. Boulder, CO: Westview Press.

Levenda, Peter. 2002. Unholy Alliance: A History of Nazi Involvement with the Occult. 2nd ed. London: Continuum.

Levtzion, Nehemia. 1999. “Aspects of Islamization: Weber's Observations on Islam Reconsidered.” Pp. 153-161 in Max Weber and Islam, ed. Toby E. Huff and Wolfgang Schluchter. New Brunswick, NJ: Transaction Publishers.

Lewis, I. S. [1971] 2003. Ecstatic Religion: An Anthropological Study of Spirit Possession and Shamanism. 3rd ed. London: Routledge.

Malinowski, Bronislaw. [1922] 2013. Argonauts of the Western Pacific: An Account of Native Enterprise and Adventure in the Archipelagoes of Melanesian New Guinea. Long Grove, IL: Waveland Press.

Malinowski, Bronislaw. [1935] 1965. Coral Gardens and Their Magic: The Language of Magic and Gardening. Vol. 2. Bloomington: Indiana University Press.

Malinowski, Bronislaw. 1948. Magic, Science and Religion, and Other Essays. New York: Doubleday.

Mauss, Marcel. [1902] 2001. A General Theory of Magic. Trans. Robert Brain. London: Routledge.

Metcalf, Peter. 2002. They Lie, We Lie: Getting on with Anthropology. London: Routledge.

Morris, Brian. 1987. Anthropological Studies of Religion. Cambridge: Cambridge University Press.

Morris, Brian. 2006. Religion and Anthropology: A Critical Introduction. Cambridge: Cambridge University Press.

Nietzsche, Friedrich. 2000. "On the Genealogy of Morals." Pp. 437-600 in Basic Writings of Nietzsche, ed. Walter A. Kaufmann. New York: Random House.

Otto, Ton. 2006. "Conceptions of Warfare in Western Thought and Research: An Introduction." Pp. 23-28 in Warfare and Society: Archaeological and Social Anthropological Perspectives, ed. Ton Otto, Henrik Thrane, and Helle Vandkilde. Aarhus: Aarhus University Press.

Reay, Marie. 1987. “The Magico-Religious Foundations of New Guinea Highlands Warfare." Pp. 83-120 in Stephen 1987b. 
Reid, Anthony. 1988. Southeast Asia in the Age of Commerce, 1450-1680. Vol. 1: The Lands Below the Winds. New Haven, CT: Yale University Press.

Ross, Anne. 2004. Druids: Preachers of Immortality. Gloucestershire: Tempus.

Russell, Jeffrey B., and Brooks Alexander. [1980] 2007. A History of Witchcraft: Sorcerers, Heretics and Pagans. 2nd ed. New York: Thames \& Hudson.

Shahar, Meir. 2008. The Shaolin Monastery: History, Religion, and the Chinese Martial Arts. Honolulu: University of Hawai'i Press.

Shaw, William. 1976. Aspects of Malayan Magic. Kuala Lumpur: Yau Seng Press.

Singer, Andre, dir. 1985. Bronislaw Malinowski: Off the Veranda. 52 min. Documentary film in the series "Strangers Abroad: Pioneers of Social Anthropology." Distributed by Films for the Humanities and Sciences.

Sørensen, Jesper. 2007. A Cognitive Theory of Magic. Lanham, MD: AltaMira Press.

Spiro, Melford E. 1987. Culture and Human Nature. Chicago: University of Chicago Press.

Stein, Rebecca L., and Philip L. Stein. 2008. The Anthropology of Religion, Magic, and Witchcraft. 2nd ed. Boston: Pearson Education.

Stephen, Michele. 1987a. "Master of Souls: The Mekeo Sorcerer.” Pp. 41-80 in Stephen 1987b.

Stephen, Michele, ed. 1987b. Sorcerer and Witch in Melanesia. New Brunswick, NJ: Rutgers University Press.

Stoller, Paul. 1997. Sensuous Scholarship. Philadelphia: University of Pennsylvania Press. Tambiah, Stanley J. 1968. “The Magical Power of Words.” Man (n.s.) 3, no. 2: 175-208.

Tambiah, Stanley J. 1976. World Conqueror and World Renouncer: A Study of Buddhism and Polity in Thailand against a Historical Background. Cambridge: Cambridge University Press.

Tambiah, Stanley J. 1985. "A Performative Approach to Ritual.” Pp. 123-166 in Culture, Thought, and Social Action: An Anthropological Perspective. Cambridge, MA: Harvard University Press.

Tambiah, Stanley J. 1990. Magic, Science, Religion, and the Scope of Rationality. Cambridge: Cambridge University Press.

Taussig, Michael. 1987. Shamanism, Colonialism, and the Wild Man: A Study in Terror and Healing. Chicago: University of Chicago Press.

Turner, Bryan S. 1998. Weber and Islam. London: Routledge.

Turner, Edith, with William Blodgett, Singleton Kahona, and Fideli Benwa. 1992. Experiencing Ritual: A New Interpretation of African Healing. Philadelphia: University of Pennsylvania Press.

Turner, Victor W. 1961. Ndembu Divination: Its Symbolism and Techniques. Manchester: Rhodes-Livingstone Institute, Manchester University Press.

Turner, Victor W. 1967. The Forest of Symbols: Aspects of Ndembu Ritual. Ithaca, NY: Cornell University Press.

Turner, Victor W. 1969. The Ritual Process: Structure and Anti-Structure. Chicago: Aldine Publishing.

Turner, Victor W. 1975. Revelation and Divination in Ndembu Ritual. Ithaca, NY: Cornell University Press.

Turner, Victor W. 1985. "An Anthropological Approach to the Icelandic Saga." Pp. 71-93 in On the Edge of the Bush: Anthropology as Experience, ed. Edith L. B. Turner. Tucson: University of Arizona Press.

Virilio, Paul. 2004. The Paul Virilio Reader. Ed. Steve Redhead. New York: Columbia University Press.

Waterson, Roxana. 1995. "Entertaining a Dangerous Guest: Sacrifice and Play in the Ma'pakorong Ritual of the Sa'dan Toraja.” Oceania 66, no. 2: 81-102. 
Weber, Max. [1905] 2002. The Protestant Ethic and the "Spirit" of Capitalism and Other Writings. Ed. and trans. Peter Baehr and Gordon C. Wells. New York: Penguin Books.

Weber, Max. [1922] 1991. The Sociology of Religion. Trans. Ephraim Fischoff. Boston: Beacon Press.

Weber, Max. 1978. Economy and Society: An Outline of an Interpretive Sociology. 2 vols. Ed. Guenther Roth and Claus Wittich. Berkeley: University of California Press.

Whitehead, Neil L. 2002. Dark Shamans: Kanaimà and the Poetics of Violent Death. Durham, NC: Duke University Press.

Whitehead, Neil L., and Robin Wright, eds. 2004. In Darkness and Secrecy: The Anthropology of Assault Sorcery and Witchcraft in Amazonia. Durham, NC: Duke University Press.

Winstedt, Richard. [1925] 1993. The Malay Magician: Being Shaman, Saiva and Sufi. Oxford: Oxford University Press. 